\title{
Phylogeny AND Biogeography of the SARRACEniaceAe
}

\author{
JoHN BRITTNACHER • Ashland, Oregon・USA・john@carnivorousplants.org
}

Keywords: History: Sarraceniaceae evolution

The carnivorous plant family Sarraceniaceae in the order Ericales consists of three genera: Darlingtonia, Heliamphora, and Sarracenia. Darlingtonia is represented by one species that is found in northern California and western Oregon. The genus Heliamphora currently has 23 recognized species all of which are native to the Guiana Highlands primarily in Venezuela with some spillover across the borders into Brazil and Guyana. Sarracenia has 15 species and subspecies, all but one of which are located in the southeastern USA. The range of Sarracenia purpurea extends into the northern USA and Canada. Closely related families in the plant order Ericales include the Roridulaceae consisting of two sticky-leaved carnivorous plant species, Actinidiaceae, the Chinese gooseberry family, Cyrillaceae, which includes the common wetland plant Cyrilla racemiflora, and the family Clethraceae, which also has wetland plants including Clethra alnifolia.

The rather charismatic plants of the Sarraceniaceae have drawn attention since the mid $19^{\text {th }}$ century from botanists trying to understand how they came into being, how the genera are related to each other, and how they came to have such disjunct distributions. Before the advent of DNA sequencing it was very difficult to determine their relationships. Macfarlane $(1889,1893)$ proposed a phylogeny of the Sarraceniaceae based on his judgment of the overlap in features of the adult pitchers and his assumption that Nepenthes is a member of the family (Fig. 1a). He based his phylogeny on the idea that the pitchers are produced from the fusion of two to five leaflets. Goebel (1891) strenuously objected to the leaflet idea but Macfarlane did not accept or understand Goebel's arguments (Macfarlane 1893). Macfarlane placed Heliamphora more ancestral to Darlingtonia and Sarracenia because of the perceived complexity and similarities in structure between Darlingtonia and Sarracenia and he believed the pitchers of Heliamphora are intermediate between the Darlingtonia/Sarracenia pair and Nepenthes. Both Nepenthes and Heliamphora have double "dorsal flaps" with those of Nepenthes being farther apart. Of course we know today that Nepenthes is in a totally different plant order and the pitchers of all four genera develop as if from one simple folded leaf (cf. Lloyd 1942).

Goebel (1891), Lloyd (1942), and Franck (1976) offered additional views on pitcher development and morphology. But unlike Macfarlane they were not champions for Darwinism so did not feel compelled to discuss their observations in an evolutionary context. And unlike Macfarlane they had access to more plant samples and studied the juvenile plants in much more detail. Goebel actually started Darlingtonia and Sarracenia from seed, studied the seedlings in detail, and lamented the fact he could not get any Heliamphora seeds. Lloyd, who studied under Goebel, did extensive field studies and saw variations in pitcher structure that are not typically seen in cultivated plants. Lloyd also confirmed and expanded on Goebel's observations of developing leaves. Except for removing Nepenthes from the phylogeny none of this work helped improve our understanding of the relationships between the genera.

Franck (1976) did the most important morphological work with respect to evolutionary biology. He showed that the juvenile pitchers of Darlingtonia are not immature versions of adult pitchers. The juvenile pitchers have significantly different developmental patterns from the adult pitchers 
(a)

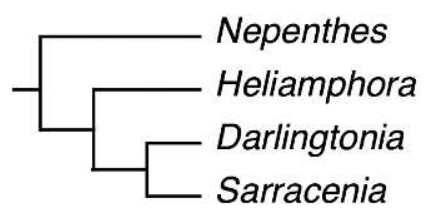

Macfarlane (1893)

Adult pitcher morphology

(c)

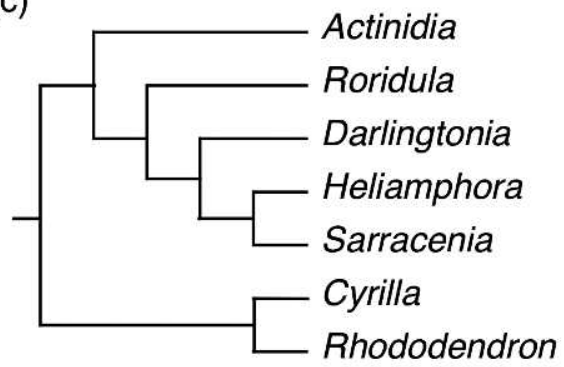

Bayer et al. (1996)

Chloroplast $r b c L$ DNA sequence (b)

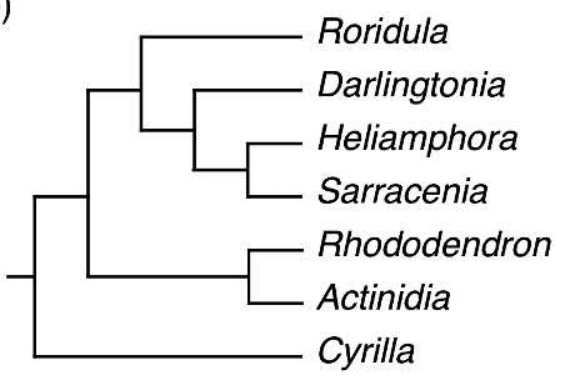

Albert et al. (1992)

Chloroplast $r b c L$ DNA sequence

(d)

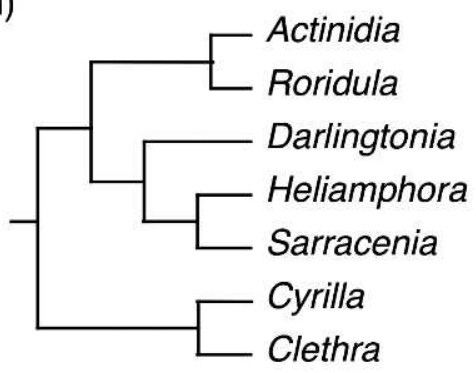

Ellison et al. (2012)

Chloroplast, mitochondria, \& nuclear DNA sequences

Figure 1: Phylogenies produced in studies of the Sarraceniaceae and the data on which each phylogeny was based. The length of the lines is arbitrary.

when compared to what is typically found in other plants that change leaf morphology as they grow. All the previous authors had assumed the juvenile pitchers were developmentally immature forms of the adult pitchers and thus not that interesting. I expect a study of Heliamphora adult and juvenile pitcher development would give similar results. However even today the juvenile pitchers of Heliamphora are pretty much ignored (e.g. McPherson et al. 2011) if not misunderstood. Juvenile Heliamphora pitchers may not provide much taxonomic value but like Darlingtonia juvenile pitchers are exquisitely adapted for trapping in a different way from the adult pitchers.

If the Sarraceniaceae is not related to Nepenthes, what is the family related to? The plant families closest to the Sarraceniaceae could not be determined from morphological details even as late as 1975. DeBuhr (1975) did a comparative study of the Sarraceniaceae in relation to other families in the Ericales to assign it to a suborder. Based on stamen morphology and number he placed the Sarraceniaceae in the suborder Theineae that contained the tea family, Theaceae, and the Actinidiaceae and not in the suborder Clethrineae with the families Clethraceae and Cyrillaceae. In retrospect the definition of Theineae was overly broad and almost a catchall suborder while the Clethrineae was too narrow based on incomplete information and the use of pollination-associated adaptations. The curious genus Purdiaea now placed in the Clethraceae based on DNA sequenc- 
ing is from Central America, northern South America, and Cuba and matches the Sarraceniaceae in number of stamens (Anderberg \& Zhang 2002) but did not fit the earlier definition of the Clethrineae. Species in the Clethraceae (as well as some in the Actinidiaceae) have poricidal anthers, another character used to define the suborder Clethrineae. Poricidal anthers fold in making a tube to protect the pollen from rain and fog. There are pores at the downward end of the anthers where the pollen falls out when the anthers are vibrated by bees. Heliamphora has this feature but the pore is not as fully defined as it is in typical poricidal anthers (Renner 1989) so DeBuhr did not observe it in his dried material. Taxonomists like characters like poricidal anthers because they can be seen in dried flowers. Unfortunately they are not really appropriate for use in taxonomy above species level because they are climate and pollinator adaptations that have arisen separately in many plant groups (Renner 1989).

A full understanding of the phylogenetic context of the Sarraceniaceae was not approached until a DNA sequence study done by Albert et al. (1992). This study used the DNA sequences of the chloroplast $r b c L$ gene to place the carnivorous plant genera among 72 plant families. They used this sequence because it changes slowly and helps resolve relationships well at the genus and family level. The study showed unequivocally that Nepenthes is related to Drosera, Dionaea, Drosophyllum, and Plumbago while the genera in the Sarraceniaceae are related to Roridula as well as Rhododendron and Actinidia (Fig. 1b). The results of the study showed that gross physical characteristics like those used by Macfarlane cannot be used to determine relationships among carnivorous plant genera. There are too many cases where unrelated carnivores have superficially identical adaptations. They also showed that Darlingtonia is the most basal species in the Sarraceniaceae. This result was so surprising that the next major study by Bayer et al. (1996) repeated the sequencing of Darlingtonia chloroplast $r b c L$. The Bayer et al. (1996) study confirmed the Albert et al. (1992) study placement of Darlingtonia but shuffled around the related genera (Fig. 1c).

The reshuffling in the phylogenies reflects the minimal amount of useful data that can be obtained from studying only one or a few genes. DNA sequences that code for proteins or other cellular components are useful in phylogenetic studies of families and orders because the sequences change slowly over time. The kinds of changes seen are limited by the need of the plant to maintain a functional gene product. The DNA sequences of non-coding regions are useful for studying closely related species. They display more and different kinds of changes resulting in proportionally more useful phylogenetic information. But as species become more distantly related there can be so many changes in non-coding regions that analysis becomes difficult. These tradeoffs mean the sequence regions used in a study need to match the expected relatedness of the taxa and that enough sequence needs to be recovered to make sure there are enough meaningful changes in the data to draw valid conclusions. In addition, studies using nuclear sequences should include more than one individual per species because of the expected polymorphisms within species. As studies get more data and include additional sequence regions it is not surprising the trees change.

Owing to advances in technology Ellison et al. (2012) analyzed more than six times the sequence data than previous studies and tweaked the phylogeny further (Fig. 1d). The biggest change is Roridula being a sister group to Actinidia. The important aspect of this change is it puts Roridula and the Sarraceniaceae into an evolutionary speed perspective. Actinidia is a member of the Actinidiaceae, a family of about 360 species in three genera. The genera and species of the Actinidiaceae had to evolve after the split with Roridula and that had to happen after both split from the Sarraceniaceae. However there is no way of knowing at this point if the Ellison et al. (2012) phylogeny will have the last word in the families related to the Sarraceniaceae and their relationships. Future studies with even more data may result in a shuffle of the related families again. 
The primary focus of the Bayer et al. (1996) study was species level relationships. They used the faster evolving nuclear DNA sequence: ribosomal RNA internal transcribed spacer, or ITS for short. This sequence is usually useful in separating taxa at the species level. Using ITS appeared to work for the three Heliamphora species tested but not for the nine Sarracenia species in the study. They were not able to recover enough sequence data to uniquely identify species. Neyland and Merchant (2006) made a second attempt at determining the phylogenetic relationships among the Sarracenia species using part of the 26S rRNA sequence plus adjacent ITS sequences. With the increased amount of sequence they were able to separate the clade consisting of $S$. purpurea and $S$. rosea from the other species in the genus and that was about it. Ellison et al. (2012) acquired even more nuclear sequences adding more 26S rRNA sequence as well as PHYC. Taken separately the Ellison et al. (2012) data give some hints at further species associations in Sarracenia but I do not consider the results significant. The major reason is not enough differences were found between species and they sampled only one individual per sequence per species.

Neyland and Merchant (2006) showed that at least for nuclear sequences it is necessary to sample more than one individual of each species when the species are as closely related as they are in Sarracenia. They reported on six individuals of Sarracenia alata and three of S. leucophylla as well as one individual for each of the other species. Based on the sequence data they posted to NCBI Genbank, they did not find any single site that unambiguously differentiated $S$. alata and $S$. leucophylla from the species other than S. purpurea and S. rosea. However three of the S. alata and one of S. leucophylla individuals sampled had unique base substitutions or insertions. This implies you can get a different answer by picking the right, or wrong, individual for DNA sequencing. Schnell and Krider (1976) and McPherson and Schnell (2011) comment on this state of affairs indirectly. They established sets of physical characters that define Sarracenia species but cautioned that the character state sets are not appropriate for determining relationships between species. Even more importantly, although they can establish an ideal for each species as they define them, when one goes out into the field, masses of hybrids are found unless a site is remote from other sites and contains only one species. And even in isolated single species sites within the extended Sarracenia rubra complex there are individuals that do not necessarily match the type of that particular species or subspecies.

It is now possible to do the kinds of DNA sequencing studies necessary to understand genera like Sarracenia. Zellmer et al. (2012) performed an ecological genetics demonstration study using "Next-generation" sequencing technologies designed for whole genome sequencing in a very clever way to generate a massive amount of sequence data for Sarracenia alata. They sequenced 86 individuals from 10 sites across the species range and compared the genetic divergence between populations to physical barriers such as the Mississippi River basin and correlated the divergence to specific local environmental factors. They estimated the eastern and western populations of $S$. alata have been separated by 60,000 generations (or a minimum of 300,000 years). However in their analysis Zellmer et al. (2012) made the assumption that Sarracenia species are reproductively isolated from each other. Four other Sarracenia species co-occur with S. alata in the eastern part of its range. Hybrids involving S. alata are commonly found today in Mississippi and Alabama (Sheridan 1991; McPherson \& Schnell 2011). It is quite possible past hybridization resulted in introgression of genetic material into $S$. alata from other species. The presence of genetic material from other species in the eastern population would make the length of time the eastern and western populations were separated to appear longer than actually happened.

DNA sequence data provide a molecular clock according to base substitution rates. With proper scaling and reference points one can estimate dates of divergence of taxa. Ellison et al. (2012) used 


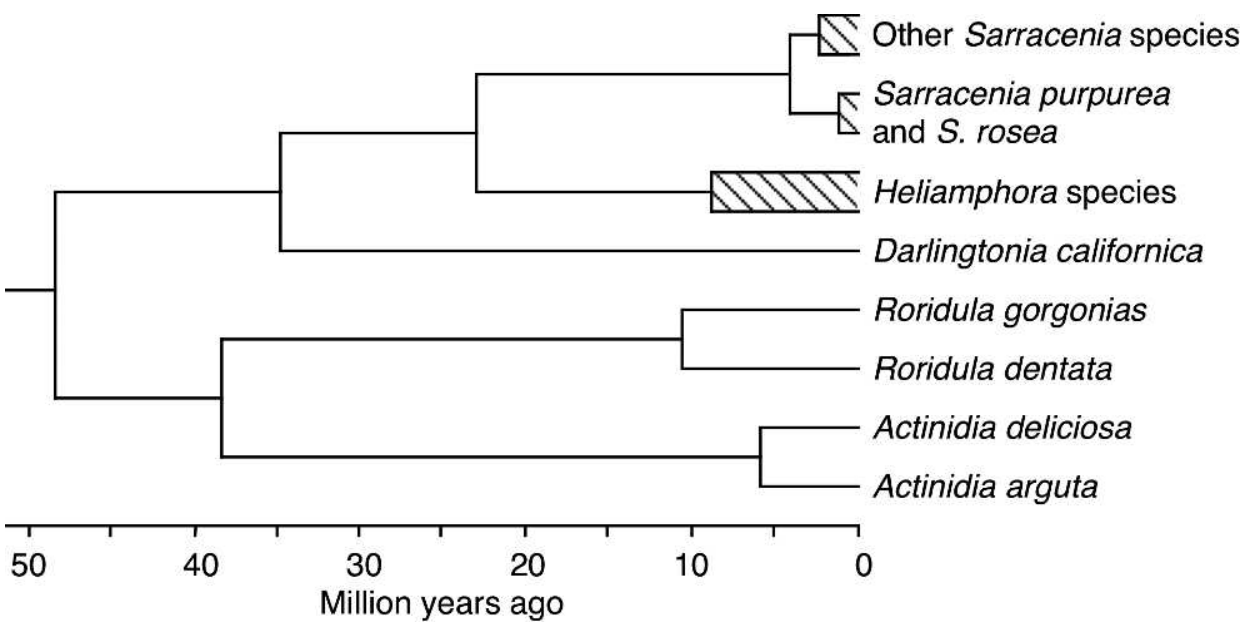

Figure 2: Phylogeny of the Sarraceniaceae calibrated to a time scale. Hatched areas indicate multiple species. Figure adapted from Ellison et al. (2012). Estimates of errors in the dates are not shown.

their data to put dates on events within the Sarraceniaceae to help understand the biogeography of the family (Fig. 2). To add dates they used techniques and fossil calibrations from Bell et al. (2010). Bell et al. (2010) place the first Ericales at about 120 million years ago. Coincidentally that is approximately the age of the possible pitcher plant Archaeamphora longicervia of Li (2005). This fossil cannot be a member of the Sarraceniaceae because it is 80 million years too old. Ellison et al. (2012) estimated the Sarraceniaceae came into existence between 35 and 48 million years ago. There are large uncertainties in these numbers, some of which result from scaling uncertainty and some from sampling error. Taken at face value the split between the Sarraceniaceae and Roridula/ Actinidiaceae clade was about 48 million years ago. The plants most likely did not have pitcher leaves at that point. Unless Darlingtonia developed pitchers separately from the other members of its family, by about 35 million years ago the Sarraceniaceae existed as pitcher plants. That is a time span of 13 million years to develop pitchers. The split between Sarracenia and Heliamphora is placed at about 23 million years ago, 12 million years after the Darlingtonia split.

The families related to the Sarraceniaceae generally have a South American focus but are by no means restricted there. Roridula is only found in South Africa and the species in the Actinidiaceae extant today are found in eastern Asia as well as Central and South America. During this time, although there were no confirmed land bridges between North and South America, based on fossils there was movement of mammals from South America into the Antilles and from North America into South America. These were singular events that happened well before North and South America became connected via Panama 4 million years ago. Ellison et al. (2012) proposed that the Sarraceniaceae arose in South America, spread to North America via the Antilles, and then fragmented first between western and eastern North America and then between eastern North America and South America. Darlingtonia is what is left of the western North American fragment, Sarracenia from the eastern North American fragment, and Heliamphora from South American fragment. On the other hand, Bayer et al. (1996) argued there is no way to discern where the Sarraceniaceae originated with any confidence. The current distribution of genera could easily be the result of two long distance dispersal events with the first event originating either in North or South America. There are plenty of 
examples of plants moving between North and South America during this time without land bridges presumably by migrating birds. Although none of the species in the family have typical adaptations for attracting birds to their seeds, birds would be expected to eat the seeds on the ground. Darlingtonia seeds are adapted for dispersal by mammals but that could be a relatively recent development.

Of course there is no way to know the actual history of the Sarraceniaceae without more data than we have today. The results of the studies show long lines of 10 to 35 million years without any branches. That does not mean there was only one species during that time. It means with the data we have there is no evidence of the species that undoubtedly existed but went extinct. Also the branch points are not literally where a new genus or species came into being. The branch points are estimates of when two genetic lines diverged. Those separate lines may not become distinct species until much later. What the data from the Ellison et al. (2012) study do tell us are the approximate times of the major splits that led to the genera and species and how long the genera and species as we know them have been separate genetic entities. For Heliamphora Ellison et al. (2012) studied six species and the oldest branch point is 9 million years ago. Presuming that date holds after a study of the whole genus is published, the genus has diversified from effectively one species into 23 across $800 \mathrm{~km}$ in 9 million years. The Sarracenia species oldest branch point is 4 million years ago and the genus developed from effectively one species into 15 species and subspecies across $2000 \mathrm{~km}$ since that time.

In spite of these results showing very fast diversification in Heliamphora and Sarracenia, Ellison et al. (2012) proposed that a species was able to sufficiently exchange genetic material across the $3500 \mathrm{~km}$ between North and South America to remain one species over 12 million years. And what about the 14 and 19 million year intervals between the split between the genera and the recent diversification? If Heliamphora was really in the Guiana Highlands before the diversification was there an extinction event that reduced the genus to one species? Or were they somewhere else where they went extinct and we now only see the results of a long distance dispersal event 9 million years ago? The only evidence I see weighing on this issue is all Heliamphora species have an adaptation found in high elevation equatorial plants: the leaves totally wrap the apical meristem and protect it and emerging leaves from nighttime frosts. McPherson (2008) explains it is unlikely the tepuis experienced extensive freezes or frosts as freezing would have accelerated the demise of the tepuis. So why would Heliamphora have the feature unless it lived in an area that did get frosts at random times during the year? Darlingtonia and Sarracenia do not protect their meristem in the same way because they are adapted to a temperate environment and go dormant seasonally. For the Sarracenia phylogeny the situation is similar to Heliamphora with a long branch and then a recent explosion. If Sarracenia as we know it was in what today is the southeast USA it was effectively reduced to one species going forward 4 million years ago. If it was somewhere else, that is when it arrived.

Ellison et al. (2012) were not able to discern much structure within Sarracenia but within Heliamphora from their limited data it appears there is no correlation between physical distance between species and genetic distance. For instance they show Heliamphora neblinae and H. pulchella to be separated temporally by only 600,000 years but they are separated spatially by $600 \mathrm{~km}$ with no current Heliamphora habitat in between while H. minor and H. heterodoxa, $55 \mathrm{~km}$ apart, are separated genetically by the 9 million years. This implies that the Heliamphora species are capable of long distance dispersal, and are not relics that speciated in place as the tepuis eroded. These results are similar to the DNA study of Kok et al. (2012) for frogs and lizards in the Guiana Highlands and are consistent with the biogeographic studies of the Guiana Highland flora by Huber (1988) and birds by Mayr and Phelps (1967). Each of these studies discussed in general terms the implications of their work but Rull (2005) proposed an explicit model explaining their results where the biota of 
Guiana Highlands have undergone elevation shifts during global climate cycles leading to mixing of species at lower elevations off the tepui tops during colder periods followed by isolation back on the tepui summits during interglacial times.

With each step in the story of the Sarraceniaceae it has gotten more complex and if anything more confusing. The comparative taxonomy got us nowhere and one could even begin wondering at what point the family developed effective pitchers and if it did so more than once. There was certainly plenty of time for independent development. The molecular genetics told us that in spite of deep roots the current set of species in Heliamphora and Sarracenia are very recent. Because all Heliamphora and Sarracenia species are interfertile and hybridization and introgression have probably been major factors in the diversification of the genera, a deeper study of their genomes using the techniques of Zellmer et al. (2012) with wild collected samples of multiple individuals in each population and large amounts of random sequences is necessary to go the next step in understanding evolution within these genera. The Sarracenia study has to be done soon before populations of pure Sarracenia species no longer exist. On the bright side we are only losing 4 million years of evolution when the genus Sarracenia has devolved into a massive hybrid swarm.

Acknowledgements: I thank the anonymous reviewers for helpful comments.

\section{References}

Albert, V.A., Williams, S.E., and Chase, M.W. 1992. Carnivorous plants: phylogeny and structural evolution. Science 257: 1491-1495.

Arne A., Anderberg, A.A., and Zhang, X. 2002. Phylogenetic relationships of Cyrillaceae and Clethraceae (Ericales) with special emphasis on the genus Purdiaea Planch. Org. Divers. Evol. 2: $127-137$

Bayer, R.J., Hufford, L., and Soltis, D.E. 1996. Phylogenetic relationships in Sarraceniaceae based on $r b c L$ and ITS sequences. Syst. Bot. 21: 121-134.

Bell, C.D., Soltis, D.E., and Soltis, P.S. 2010. The age and diversification of the angiosperms rerevisited. Am. J. Bot. 97: 1296-1303.

DeBuhr, L.E. 1975. Phylogenetic relationships of the Sarraceniaceae. Taxon 24: 297-306.

Ellison, A.M., Butler, E.D., Hicks, E.J., Naczi, R.F.C., Calie, P.J., Bell, C.D., and Davis, C.C. 2012. Phylogeny and biogeography of the carnivorous plant family Sarraceniaceae. PLoS ONE 7(6): e39291. doi:10.1371/journal.pone.0039291.

Franck, D.H. 1976. Comparative morphology and early leaf histogenesis of adult and juvenile leaves of Darlingtonia californica and their bearing on the concept of heterophylly. Bot. Gaz. 137(1): 20-34.

Goebel, K. 1891. Pflanzenbiologische Schilderungen. Part 2, V. Insektivoren. Marburg.

Huber, O. 1988. Guayana lowlands versus Guayana highlands, a reappraisal. Taxon 37: 595-614.

Kok, P.J.R., MacCulloch, R.D., Means, D.B., Roelants, K., Van Bocxlaer, I., and Bossuyt, F. 2012. Low genetic diversity in tepui summit vertebrates. Current Biology 22(15): R589-R590.

Li, H. 2005. Early Cretaceous sarraceniacean-like pitcher plants from China. Acta Bot. Gall. 152: 227-234

Lloyd, F.E. 1942. The Carnivorous Plants. Chronica Botanica, Waltham, MA.

Macfarlane, J.M. 1889. Observations on pitchered insectivorous plants. (Part I.). Annals of Botany 3(10): 253-266.

Macfarlane, J.M. 1893. Observations on pitchered insectivorous plants. (Part II.). Annals of Botany 7(4): 403-455. 
Mayr, E., and Phelps, W.H. 1967. The origin of the bird fauna of the South Venezuelan Guayana. Bulletin of the American Museum of Natural History 136: 273-327

McPherson, S. 2008. Lost Worlds of the Guiana Highlands. Redfern Natural History Productions Ltd., Poole.

McPherson, S., and Schnell, D. 2011. Sarraceniaceae of North America. Redfern Natural History Productions Ltd., Poole.

McPherson, S., Wistuba, A., Fleischmann, A., and Nerz, J. 2011. Sarraceniaceae of South America. Redfern Natural History Productions Ltd., Poole.

Neyland, R., and Merchant, M. 2006. Systematic relationships of Sarraceniaceae inferred from nuclear ribosomal DNA sequences. Madroño 53: 223-232.

Renner, S.S. 1989. Floral biological observations on Heliamphora tatei (Sarraceniaceae) and other plants from Cerro de la Neblina in Venezuela. Plant Syst. Evol. 163: 21-29.

Rull, V. 2005. Biotic diversification in the Guayana Highlands: a proposal. J. Biogeogr. 32: 921-927.

Schnell, D., and Krider, D.W. 1976. Cluster analysis of the genus Sarracenia L. in the southeastern United States. Castanea 41: 165-176.

Sheridan, P.M. 1991. What is the identity of the west gulf coast pitcher plant, Sarracenia alata Wood? Carniv. Pl. Newslett. 20(4): 102-110

Zellmer, A.J., Hanes, M.M., Hird, S.M., and Carstens, B.C. 2012. Deep phylogeographic structure and environmental differentiation in the carnivorous plant Sarracenia alata. Syst. Biol. 61(5): 763-777.
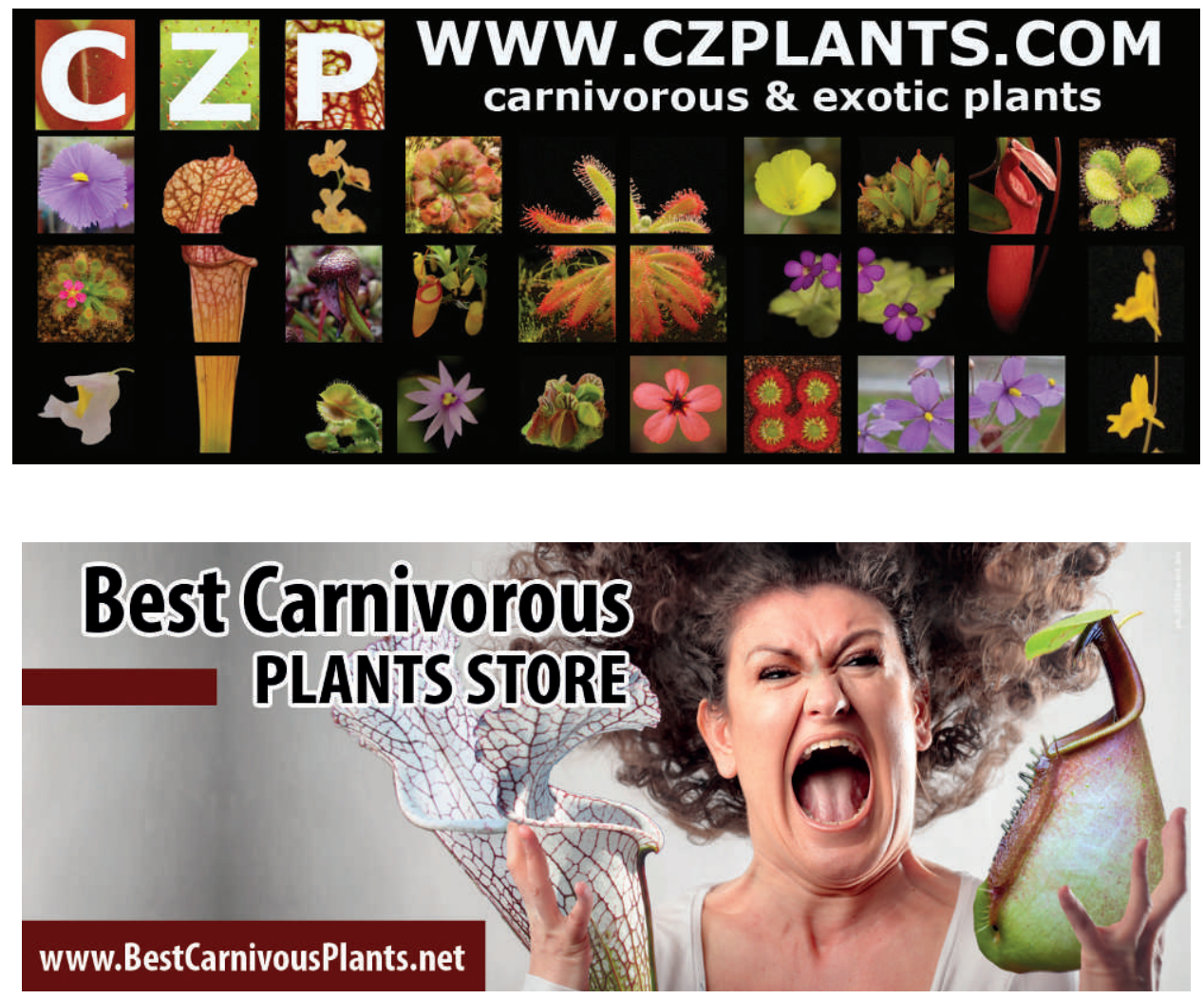